\title{
Epidemiological and histopathological aspects of primary cutaneous melanoma in residents of Joinville, 2003-2014*
}

\author{
Raquel Bissacotti Steglich ${ }^{1}$ \\ Silvana Cardoso ${ }^{2}$ \\ Tania Ferreira Cestari ${ }^{3}$
}

\author{
Karina Munhoz de Paula Alves Coelho ${ }^{1}$ \\ Maria Helena da Costa Naumann Gaertner ${ }^{2}$ \\ Selma Cristina Franco ${ }^{4}$
}

DOI: http:/ / dx.doi.org/10.1590/abd1806-4841.20185497

\begin{abstract}
BACKGROUND: The worldwide incidence of cutaneous melanoma (CM) has been continuously increasing over the last decades. Primary and secondary prevention, with attention to risk factors and early diagnosis, remain the cornerstone for reducing the burden of cutaneous melanoma. Detailed information with respect to clinical and pathological data on cutaneous melanoma is scarce in Brazil.

Овлестіvе: The purpose of our study was to analyze epidemiological and pathological characteristics of primary cutaneous melanoma in Joinville, southern Brazil.

METHODS: Observational, cross-sectional, retrospective study in which 893 reports of primary cutaneous melanoma from the local population were analyzed in the period 2003-2014. The study was approved by the local Ethics and Research Committee.

RESULTS: We observed a female predominance of cutaneous melanoma (56.3\%). The age standardized incidence rate of primary cutaneous melanoma for the world population in the period 2003-06 was 11.8 per 100,000 population (CI 95\%, 10.3-13.4), and 17.5 (CI 95\%, 15.7-19.3) in 2011-14, revealing a significant increase of $48.3 \%(p<0,05)$. Six and a half percent of patients had multiple cutaneous melanomas (mean 2.2 years and a maximum of 10.0 years between diagnoses). We observed significant differences between the location head/neck and cutaneous melanoma in situ, lower limb with Breslow depth S III and upper limb with Breslow depth S I. The comparison of the characteristics of cutaneous melanoma in the elderly and non-elderly (< 60 years old) showed significant differences with respect to all the variables studied.

STUDY LIMITATIONS: Using secondary data source.

CONCLUSION: Joinville has high incidence coefficients for Brazilian standards, showing an increase in the incidence of cutaneous melanoma.
\end{abstract}

Keywords: Melanoma; Public health; Skin neoplasms

\section{INTRODUCTION}

Melanoma is a usually aggressive malignant neoplasm of neuroectodermal origin arising from activated and genetically altered melanocytes. ${ }^{1,2}$ Although cutaneous melanomas (CM) represent only $4-5 \%$ of the skin neoplasias, they have great clinical and epidemiological relevance for being responsible for up to $80 \%$ of the deaths caused by skin cancer.,

The recognition of risk factors for CM development is important from both clinical and public health perspectives. ${ }^{5}$ Multiple risk factors have been associated with $\mathrm{CM}$ development such as skin, fair hair, light eyes, European ancestry, large numbers of acquired nevi, presence of atypical nevi, personal or family history of CM, advanced age, male sex, xeroderma pigmentosum, sunburn, and increased exposure to ultraviolet radiation (UVR) ${ }^{1,6}$ Some other risk factors include freckles later in life, smoking, obesity, Parkinson's disease, immunosuppression, and home or professional use of pesticide. However, more studies are needed to evaluate the strength of these associations. ${ }^{7-13}$

Incidence rates of $\mathrm{CM}$ have increased globally.,14 In Australia, the country with the highest CM incidence rates, this is the fourth most prevalent tumor responsible for $10.2 \%$ of all new cancer cases. In 2015, 12,960 new cases of CM were expected, with an estimated incidence of 49 cases per 100,000 population. Its age-adjusted

\footnotetext{
Received on 11.12.2015.

Approved by the Advisory Board and accepted for publication on 06.10.2016.

* Work performed at Universidade da Região de Joinville (UNIVILLE) - Joinville (SC), Brazil.

Financial support: None.

Conflict of interest: None.

Private clinic - Joinville (SC), Brazil

Academy of the Universidade da Região de Joinville (UNIVILLE) - Joinville (SC), Brazil.

Dermatology Service at Universidade Federal do Rio Grande do Sul (UFRGS) - Porto Alegre (RS), Brazil.

Public Health Division of the Universidade da Região de Joinville (UNIVILLE) - Joinville (SC), Brazil.
} 
incidence increased from 27 cases per 100,000 population in 1982 to 48 cases in $2011 .{ }^{15}$

In the United States, $\mathrm{CM}$ is the sixth most frequent tumor. ${ }^{16}$ In 2014, approximately 76,100 individuals were diagnosed with CM. ${ }^{17}$ Between 2008 and 2012, the incidence of CM in Americans was estimated at 21.6 per 100,000 population per year. ${ }^{16}$ The average risk of developing $\mathrm{CM}$ during lifetime in the US increased from 1 for every 1,500 people in 1935 to 1 for every 30 in 2009. ${ }^{18}$

In Europe, in 2012, the age-standardized rates of CM for both sexes among the European population was 11.1 per 100,000 population. Switzerland ranks first with a rate of 25.8 per 100,000 population, followed by Norway (25.3), the Netherlands (24.4), Denmark (24.1), Sweden (23.9), Slovenia (20.6), England (19.0), and Ireland (18.0). A second group of countries, with incidences varying between 13.1 and 16.8 cases per 100,000 population comprises, in descending order, Finland, the Czech Republic, Belgium, Greenland, Germany, Luxembourg, Italy, and Slovakia. ${ }^{19}$

In Brazil, in 2014, the National Cancer Institute (INCA) estimated the occurrence of 5,890 new CM cases, representing a gross rate of 4.3 cases in men and 4.6 cases in women per 100,000 population. ${ }^{20,21}$ Santa Catarina (SC) is the second Brazilian state with the highest incidence, second only to Rio Grande do Sul (RS). ${ }^{22}$

In the studied municipality, the gross rate of $\mathrm{CM}$ incidence in 2005 was 7.8 cases per 100,000 population. ${ }^{23}$ Founded and colonized by immigrants from Germany, Switzerland, and Norway in the $19^{\text {th }}$ century, Joinville is the most populous city in the state, predominantly white $(86 \%)$, and has one of the highest human development indexes (HDI) (0.809) among Brazilian municipalities. ${ }^{24}$

In Brazil, detailed population-based data on the incidence of $\mathrm{CM}$ according to demographic and histological characteristics are scarce. ${ }^{25}$ Deficiency of compulsory notification, lack of reliable central registration, and lack of priority by public health managers are pointed out as the main barriers to a better understanding of the problem and the implementation of control actions..$^{25}$

Therefore, the present study intends to describe the profile of primary CM among residents of a municipality in the south of Brazil, aiming to subsidize resource planning and coping strategies in order to seek the reduction of $\mathrm{CM}$ rates.

\section{METHODS}

We performed an observational, cross-sectional, retrospective study to analyze cases of primary CM recorded between January 2003 and December 2014 in the resident population of Joinville.

We collected the reports of all cases of primary CM diagnosed in the only three laboratories of Pathological Anatomy of the city, which are responsible for the diagnosis of patients residing in Joinville and surrounding cities. In order to identify and select the reports of all $\mathrm{CM}$ cases in the electronic databases of two laboratories, we used the descriptors "melanoma" and "lentigo maligna" in the diagnostic field and "skin and/or cutaneous" for the affected organ. The other laboratory used diagnostic registry books from 2003 to 2007. Therefore, data was collected manually. For the following years, data collection was similar to the other two laboratories.

Since the city of residence of patients was not available in half of the reports, we concluded our search with 3 other databases: Munic- ipal Hospital São José de Joinville (patients registered in the Brazilian Unified Health System - SUS), Centro Hospitalar Unimed de Joinville (patients with health insurance), and the place of origin of each report (SUS specialty outpatient clinics and private doctor's offices).

We used full names and dates of birth to confirm the address of the subjects and to identify the existence of multiple reports of the same case (what eventually occurs when the diagnosis is the product of incisional biopsy followed by excision or margin enlargement). In the cases of patients with reports of CMs resulting from incisional biopsy and subsequent complete excision, we considered the report with the highest Breslow thickness measure. There was no access or consultation of medical records or patients. We reviewed no histological specimens, accepting the diagnosis and the descriptions as described in the reports.

Inclusion criteria were: to be a resident of Joinville and to have a diagnosis of primary CM during the study period. Exclusion criteria were: reports of cases from other cities; cases of neoplasms affecting other organs and tissues; revision reports of surgical pathology slides; reports suggestive of melanoma, but with inconclusive diagnosis without immunohistochemical evidence; reports of residual neoplasia or enlargement of the surgical margin.

After applying the inclusion and exclusion criteria to the 1,548 existing reports, 655 reports $(42.3 \%)$ were excluded: 390 reports from residents of other cities (25.2\%); 46 melanoma metastasis reports $(3.0 \%), 144$ duplicate reports (margin enlargement, incisional biopsy followed by a complete excision, 9.30\%), 40 slide or complementary immunohistochemistry revision reports (2.6\%), and 35 for other reasons (such as inconclusive reports, other neoplasms, and neoplasms affecting a different organ, 2.3\%).

Based on these procedures, we believe that all cases of $\mathrm{CM}$ affecting individuals living in Joinville were included, qualifying our study as a population-based survey.

The data were entered in the Excel 2011 spreadsheet and then exported to the SPSS v.18.0 for statistical analysis. Categorical variables were described by frequencies and percentages. The categorical variables were then associated with the chi-square test. After that, we performed the analysis of the adjusted residuals to locate the differences pointed out by the test. Residuals with absolute values above 1.96 were considered statistically significant. We used the Z-score test to compare the difference between the coefficients of incidence with a $95 \%$ confidence interval, considering a significance level of $5 \%$.

The individuals were grouped in 2 age-classes: young (less than 60 years) and elderly (60 years and over), as defined by the WHO.

The gross rate of $\mathrm{CM}$ incidence for Joinville was calculated for each year using the following formula: number of new cases of $\mathrm{CM}$ each year divided by the population of the same year (estimated by the Brazilian Institute of Geography and Statistics - IBGE - and published on Datasus system) multiplied by 100 thousand population. ${ }^{26-29}$

In order to allow comparisons between locations with different age groups and time series analysis, we standardized the coefficients by adjusting the gross rate of $\mathrm{CM}$ incidence to the world standard population (2010) and to the Brazilian standard population (2010 census) by age group and gender. ${ }^{30-34}$

This work was approved by the Ethics Committee of the Universidade da Região de Joinville (UNIVILLE) - Joinville (SC), Brazil. 


\section{RESULTS}

We identified $819 \mathrm{CM}$ patients in the study period, of which 461 were women $(56.3 \%)$ and 358 were men $(43.7 \%)$. Table 1 shows the coefficients of incidence of primary CM in residents of Joinville from 2003 to 2014.

In Joinville, the comparison of the age-adjusted coefficient of incidence for the world standard population (CIWP) between 2003-06 (11.8, 95\% CI, 10.3-13.4) and 2011-14 (17, 5, 95\% CI, 15.7-19.3) revealed a statistically significant difference $(\mathrm{p}<0.05)$, with a $48.3 \%$ increase between the first and last quadrennium.

Likewise, the comparison of CIWPs according to gender between the same periods showed a statistically significant difference among men (11.1; 95\% CI, 9.0-13.3 and 16.0; 95\% CI: 13.6-18, respectively) and women (12.5, 95\% CI, 314.8 and 18.9, 95\% CI, 321.6, respectively) ( $\mathrm{p}<0.05)$. The increase between the first and last quadrennium was $44.0 \%$ among men and $51.2 \%$ among women.

Figure 1 shows the gender-stratified coefficients of incidence of Joinville over time.

Of the $893 \mathrm{CM}$ cases identified, the most frequent locations were the trunk and the upper limb, with a predominance of the superficial spreading melanoma (SSM) histological type, Breslow stage 1, and Clark levels III and IV. The mean age was 54.6 years, with a standard deviation of 16.5 years.

Comparison of $\mathrm{CM}$ characteristics among elderly (60 years of age or older) and non-elderly patients (under 60 years of age) showed significant differences in relation to all variables studied (Table 2). CMs located on the trunk and upper limb were more frequent in young patients while lesions located on the head and neck were more frequent in the elderly $(p<0.001)$. Regarding histological type, there was a predominance of SSM among younger patients and nodular melanoma (NM) and lentigo maligna mela- noma (LMM) among the elderly $(\mathrm{p}<0.001)$. As for Breslow depth, S1 was predominant in the group of young people and S3 and S4 in the elderly ( $p<0.001)$. Likewise, Clark level III prevailed in the younger group, and Clark IV and V in the elderly $(p<0.001)$. Most individuals with multiple CMs were elderly patients.

Regarding gender, women were more affected by $\mathrm{CM}(56.8 \%)$ (Table 3). We observed that CM were more commonly located on the lower limbs in women and, in men, in the head/neck and trunk re-

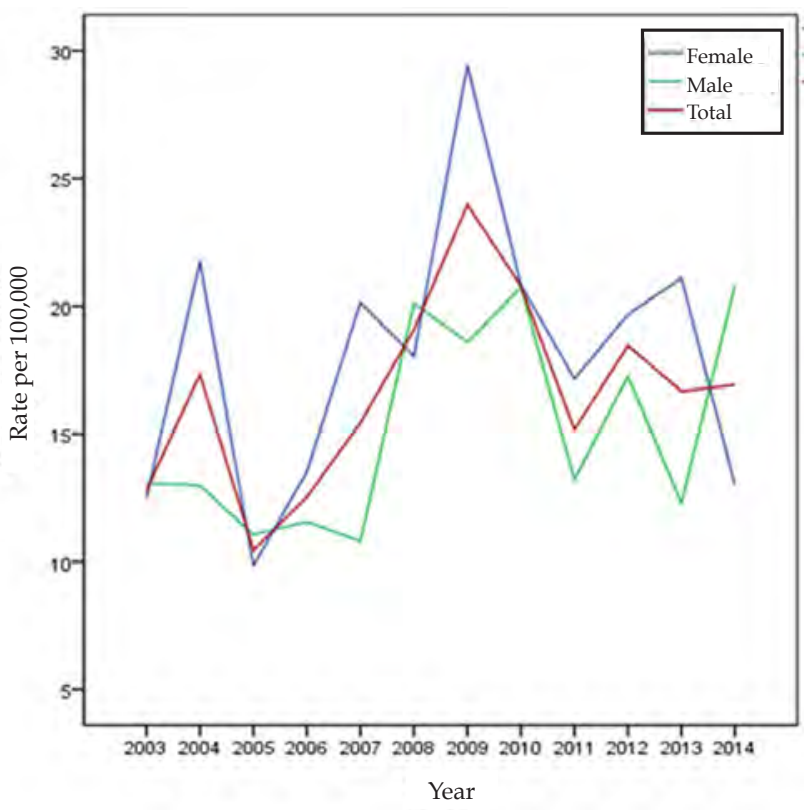

FigURE 1: Age-adjusted coefficients of annual incidence of primary $\mathrm{CM}$ by sex adapted to a world standard based population, between 2003 and 2014 for residents of Joinville

TABLE 1: Distribution of the new cases of $\mathrm{CM}$ according to the population of Joinville, gross rate of CM incidence, gender-adjusted rates, and rates adapted to the Brazilian and world standard based population each year

\begin{tabular}{|c|c|c|c|c|c|c|c|c|c|c|c|}
\hline Year & $\mathbf{N}$ & $\mathbf{P}$ & IC & CIBP & CIWP & $\begin{array}{c}\text { Female } \\
\text { IC }\end{array}$ & $\begin{array}{c}\text { Female } \\
\text { CIBP }\end{array}$ & $\begin{array}{c}\text { Female } \\
\text { CIWP }\end{array}$ & $\begin{array}{c}\text { Male } \\
\text { IC }\end{array}$ & $\begin{array}{l}\text { Male } \\
\text { CIBP }\end{array}$ & $\begin{array}{r}\text { Male } \\
\text { CIWP }\end{array}$ \\
\hline 2003 & 39 & 461,578 & 8.5 & 12.5 & 12.8 & 8.2 & 12.3 & 12.5 & 8.7 & 12.6 & 13.1 \\
\hline 2004 & 58 & 469,362 & 12.3 & 17.4 & 17.3 & 16.1 & 21.6 & 21.7 & 8.6 & 13 & 13 \\
\hline 2005 & 40 & 487,047 & 8.2 & 10.5 & 10.5 & 8.2 & 9.9 & 9.8 & 8.3 & 11 & 11.1 \\
\hline 2006 & 46 & 496,050 & 9.3 & 12.5 & 12.5 & 9.2 & 13.3 & 13.5 & 9.3 & 11.7 & 11.6 \\
\hline 2007 & 70 & 504,983 & 13.8 & 15.5 & 15.4 & 18 & 20.1 & 20.1 & 9.6 & 10.7 & 10.8 \\
\hline 2008 & 81 & 492,101 & 16.5 & 18.9 & 19.1 & 16.5 & 17.9 & 18 & 16.5 & 19.9 & 20.1 \\
\hline 2009 & 109 & 497,329 & 21.8 & 23.9 & 24 & 27.8 & 29.5 & 29.4 & 15.9 & 18.1 & 18.6 \\
\hline 2010 & 105 & 515,288 & 20.4 & 20.9 & 20.8 & 21.2 & 21.1 & 20.8 & 19.6 & 20.8 & 20.7 \\
\hline 2011 & 77 & 520,905 & 14.8 & 15.2 & 15.2 & 17.9 & 17.5 & 17.2 & 11.6 & 12.8 & 13.2 \\
\hline 2012 & 93 & 526,338 & 17.7 & 18.5 & 18.5 & 19.6 & 19.8 & 19.7 & 15.7 & 17.1 & 17.3 \\
\hline 2013 & 87 & 546,981 & 15.9 & 16.8 & 16.7 & 20.7 & 21.3 & 21.1 & 11 & 12.1 & 12.3 \\
\hline 2014 & 88 & 554,601 & 15.9 & 16.8 & 16.9 & 13.6 & 13.4 & 13 & 18.2 & 20.4 & 20.8 \\
\hline
\end{tabular}

Note: *Estimated incidence per 100,000 population; $\mathrm{N}=$ number of new cases; $\mathrm{P}=$ total population of Joinville; IC = Joinville gross coefficient of incidence; ICBP = age-adjusted coefficient of incidence for the Brazilian standard population; ICWP = age-adjusted coefficient of incidence for the world standard population 
gions $(\mathrm{p}<0.0001)$. There was no statistically significant difference between genders when comparing histological types, Breslow depth, Clark level, and occurrence of multiple CMs. However, the comparison between each histological category showed a predominance NM and SSM in men ( $p=0.026$ and $p=0.0335$, respectively).

The comparison of MC characteristics varied according to lesion location. Clark level I and V lesions were prevalent on the head and neck, and IV and V on the lower limb ( $\mathrm{p}<0.001)$. Regarding lesion thickness, in situ lesions prevailed on the head and neck; Breslow S1 on the upper limb; and Breslow S3 on the lower limb (p =
0.004). With regard to histological type, LMM prevailed on the head and neck; acral lentiginous melanoma (ALM) on the lower limb; and SSM on the upper limb and trunk $(\mathrm{p}<0.001)$ (Table 4).

Of the 819 patients, $53(6.5 \%)$ had more than one primary CM (95\% CI, 4.9\%-8.4\%). The mean time between the lesions was 2.22 years and the median was less than 1 year (0.92), with a standard deviation of 2.71 years. The minimum time was less than 1 year (with 10 cases of synchronous $\mathrm{CMs}$ ) and the maximum time was 10.05 years. The absolute majority of subjects $(74 \%)$ had up to 2 primary $\mathrm{CMs}$, followed by $23 \%$ with 3 primary CMs. Cases of multiple CMs occurred

TABLE 2: Distribution of CM cases according to anatomical site and age group in Joinville, 2003-2014

\begin{tabular}{|c|c|c|c|c|}
\hline & Total & $\begin{array}{c}\text { Young people } \\
0-59 \text { years }(n=546)\end{array}$ & $\begin{array}{c}\text { Elderly } \\
60 \text { years or older }(n=347)\end{array}$ & P-value \\
\hline $\mathrm{CM}$ characteristics & n (\%) & n (\%) & n (\%) & \\
\hline Location & & & & $<0.001$ \\
\hline Head/neck & $176(19.7)$ & 65 (11.9) & $111(32.0)^{*}$ & \\
\hline Lower limb & $166(18.6)$ & $102(18.3)$ & $64(18.4)$ & \\
\hline Upper limb & $224(25.1)$ & $154(28.2)^{*}$ & $70(20.2)$ & \\
\hline Skin, WFS & $14(1.6)$ & $9(1.6)$ & $5(1.4)$ & \\
\hline Trunk & $313(35.1)$ & $216(39.6)^{*}$ & $97(28.0)$ & \\
\hline Type & & & & $<0.001$ \\
\hline SSM & $516(57.9)$ & $367(67.3)^{*}$ & $149(43.1)$ & \\
\hline NM & $168(18.9)$ & $73(13.4)$ & $95(27.5)^{*}$ & \\
\hline LMM & $91(10.2)$ & $37(6.8)$ & $54(15.6)^{*}$ & \\
\hline ALM & $10(1.1)$ & $4(0.7)$ & $1(0.3)$ & \\
\hline NVM & $9(1.0)$ & $7(1.3)$ & $2(0.6)$ & \\
\hline DM & $5(0.6)$ & $4(0.7)$ & $1(0.3)$ & \\
\hline BNM & $1(0.1)$ & $0(0.0)$ & $1(0.3)$ & \\
\hline Melanoma, WFS & $89(10.0)$ & $50(9.2)$ & 39 (11.3) & \\
\hline Others: SM & $3(0.3)$ & $3(0.6)$ & $0(0.0)$ & \\
\hline Others: ATM & $1(0.1)$ & $0(0.0)$ & $1(0.3)$ & \\
\hline Breslow $(n=859)$ & & & & $<0.001$ \\
\hline In situ & $203(23.6)$ & 125 (23.7) & $78(23.5)$ & \\
\hline S I & $369(43.0)$ & $254(48.2)^{*}$ & 115 (34.6) & \\
\hline S II & $112(13.0)$ & $72(13.7)$ & $40(12.0)$ & \\
\hline S III & $81(9.4)$ & $37(7.0)$ & $44(13.3)^{*}$ & \\
\hline S IV & $94(10.9)$ & $39(7.4)$ & $55(16,6)^{*}$ & \\
\hline Clark $(n=864)$ & & & & $<0.001$ \\
\hline I & $203(23.5)$ & 125 (23.7) & 78 (23.1) & \\
\hline II & $173(20.0)$ & 107 (20.3) & 66 (19.6) & \\
\hline III & $232(26.9)$ & $167(31.7)^{*}$ & 65 (19.3) & \\
\hline IV & $216(25.0)$ & 114 (21.6) & $102(30.3)^{*}$ & \\
\hline V & $40(4.6)$ & $14(2.7)$ & $26(7.7)^{*}$ & \\
\hline Multiple CMs & $127(14.2)$ & $61(11.2)$ & $66(19.0)$ & 0.002 \\
\hline
\end{tabular}

Notes: $\mathbf{A L M}=$ acral lentiginous melanoma; $\mathbf{A T M}=$ equine- $/$ animal-type melanoma; $\mathbf{B N M}=$ melanoma from blue nevus; $\mathbf{C M}=$ cutaneous melanoma; $\mathbf{D M}=$ desmoplastic melanoma; LMM = lentigo maligna melanoma; $\mathbf{N M}=$ nodular melanoma; $\mathbf{N V M}=$ nevoid melanoma; $\mathbf{S M}=$ spitzoid melanoma; $\mathbf{S S M}=$ superficial spreading melanoma; and $\mathbf{W F S}=$ without further specifications 
more on the upper limb $(p=0.033)$, more frequently of the SSM type and less frequently of the NM type $(p=0.021)$.

\section{DISCUSSION}

This is the first study to approach the occurrence of primary $\mathrm{CM}$ with analysis of clinical and histological data in the city of

\begin{tabular}{|c|c|c|c|c|}
\hline \multicolumn{5}{|c|}{$\begin{array}{l}\text { TABLE 3: CM distribution according to gender in relation to } \\
\text { location, histological type, Breslow's depth, } \\
\text { and Clark's level }(n=893)\end{array}$} \\
\hline & \multirow{2}{*}{$\begin{array}{c}\text { Total } \\
(\mathrm{n}=893)\end{array}$} & \multicolumn{2}{|c|}{ Gender } & \multirow[t]{2}{*}{ P-value } \\
\hline & & $\begin{array}{l}\text { Female } \\
(n=507)\end{array}$ & $\begin{array}{c}\text { Male } \\
(n=386)\end{array}$ & \\
\hline $\mathrm{CM}$ characteristics & $\mathrm{n}(\%)$ & $\mathrm{n}(\%)$ & $\mathrm{n}(\%)$ & \\
\hline Location & & & & $<0.0001$ \\
\hline Head/neck & $176(19.7)$ & $84(16.6)$ & $92(23.8)^{*}$ & \\
\hline Lower limb & $166(18.6)$ & $127(25.0)^{*}$ & 39 (10.1) & \\
\hline Upper limb & $224(25.1)$ & $127(25.0)$ & $97(25.1)$ & \\
\hline Skin, WFS & $14(1.6)$ & $9(1.8)$ & $5(1.3)$ & \\
\hline Trunk & $313(35.1)$ & $160(31.6)$ & $153(39.6)^{*}$ & \\
\hline Type & & & & 0.341 \\
\hline SSM & $516(57.8)$ & $309(60.9)$ & $207(53.9)$ & \\
\hline NM & $168(18.8)$ & $82(16.2)$ & $86(22.4)$ & \\
\hline LMM & $91(10.2)$ & $53(10.5)$ & $38(9.9)$ & \\
\hline ALM & $10(1.1)$ & $6(1.2)$ & $4(1.0)$ & \\
\hline NVM & $9(1.0)$ & $4(0.8)$ & $5(1.3)$ & \\
\hline $\mathrm{DM}$ & $5(0.6)$ & $3(0.6)$ & $2(0.5)$ & \\
\hline BNM & $1(0.1)$ & $0(0.0)$ & $1(0.3)$ & \\
\hline Melanoma, WFS & $89(10.0)$ & $48(9.5)$ & $41(10.7)$ & \\
\hline Others: SM & $3(0.3)$ & $2(0.4)$ & $1(0.3)$ & \\
\hline Others: ATM & $1(0.1)$ & $0(0.0)$ & $1(0.3)$ & \\
\hline Breslow $(n=859)$ & & & & 0.069 \\
\hline In situ & $203(23.6)$ & $117(23.8)$ & $86(23.4)$ & \\
\hline S I & $369(43.0)$ & $223(45.3)$ & $146(39.8)$ & \\
\hline S II & $112(13.0)$ & $65(13.2)$ & 47 (12.8) & \\
\hline S III & $81(9.4)$ & $46(9.3)$ & $35(9.5)$ & \\
\hline S IV & $94(10.9)$ & $41(8.3)$ & $53(14.4)$ & \\
\hline Clark $(n=864)$ & & & & 0.663 \\
\hline I & $203(23.5)$ & $117(23.5)$ & $86(23.4)$ & \\
\hline II & $173(20.0)$ & 99 (19.9) & $74(20.2)$ & \\
\hline III & $232(26.9)$ & $142(28.6)$ & $90(24.5)$ & \\
\hline IV & $216(25.0)$ & $117(23.5)$ & $99(27.0)$ & \\
\hline V & $40(4.6)$ & $22(4.4)$ & $18(4.9)$ & \\
\hline Multiple CMs & $127(14.2)$ & $76(15.0)$ & $51(13.2)$ & 0.511 \\
\hline
\end{tabular}

Notes: ALM = acral lentiginous melanoma; $\mathbf{A T M}=$ equine-/animal-type melanoma; BNM = melanoma from blue nevus; $\mathbf{C M}=$ cutaneous melanoma; $\mathbf{D M}=$ desmoplastic melanoma; $\mathbf{L M M}=$ lentigo maligna melanoma; $\mathbf{N M}=$ nodular melanoma; $\mathbf{N V M}=$ nevoid melanoma; SSM = superficial spreading melanoma; SM = spitzoid melanoma; and WFS = without further specifications
Joinville. We observed a high incidence in relation to the expected indices for Brazil. Possible explanations for this finding are the use of recent databases (2003-2014) coming directly from reference laboratories, an important factor for a disease with an increasing incidence worldwide in recent years. In addition, Joinville is inhabited mostly by a population of fair-skinned people with an HDI above the national average who live near the coast and often take up recreational activities with intermittent sun exposure.

Currently, despite the existence of a pioneering state compulsory cancer notification system (Sistema Estadual de Registro de Câncer no Estado de Santa Catarina - SISCAN), its database is unfortunately incomplete due to underreporting of CM cases, making it impossible to conduct an actual population-based study. ${ }^{35,36}$ However, the methodological procedures adopted in the present study, especially the inclusion of all patients from all laboratories of pathological anatomy in the city and the subsequent checking of patient addresses, allowed us to conduct a study close to a population-based survey.

In 2003, CIWP of residents of Joinville was 12.8 cases per 100,000 population. The figure evolved with oscillations and increased in subsequent years, reaching 16.9 cases per 100,000 population in 2014. The weighted average of Joinville's gross rate of CM incidence in the 12 years of the study was 14.7 per 100,000 population, with a female predominance (16.5 versus 12.8 ). We observed a $48 \%$ increase between the mean of the CIWPs between the first and the last quadrennium of the study (from 11.8 to 17.5 per 100,000 population) $(\mathrm{p}<0.05)$. In the period between 2011 and 2014, the CIWP was 18.9 cases in women and 16.0 cases in men per 100,000 population.

The highest incidence rates of $\mathrm{CM}$ are found in Australia and New Zealand (40-60 cases per 100,000 population) ${ }^{10,37}$ In the USA, between 2008 and 2012, the number of new cases of CM was 28.2 in men and 16.8 in women per 100,000 population. ${ }^{16}$ The incidence of $\mathrm{CM}$ observed in Joinville is close to data from Central Europe (Germany and Italy, for example), a group of countries with high CM rates, falling behind only the Nordic countries. ${ }^{19}$ In 2005, in a rural region in northern France, the standardized incidence ratio was estimated at 8.8 in women and 7.6 in men per 100,000 population. ${ }^{38}$ In the same year, the CIWP for Joinville was 9.8 cases in women and 11.1 new cases in men per 100,000 population. The state of Santa Catarina, in 2014, presented a gross rate of CM incidence of 6.4 cases in women and 7.4 cases in men per 100,000 population. ${ }^{22}$ In the period between 2008 and 2010, Florianópolis, the capital city, had a CIWP of 13.8 cases per 100,000 population. ${ }^{39}$

Bonilla et al. (2007) published the incidence of neoplasias in the city of Joinville in 2005, and the gross rate of CM incidence was 7.8 per 100,000 population, close to the gross rate found in the present study in the same year. ${ }^{2,8}$ The small variation between the two studies is due to methodological differences, since the work of Bonilla et al. did not have access to data from one of the three laboratories in the municipality, which, at the time, was responsible for $10.6 \%$ of the biopsies performed in Joinville. ${ }^{23}$

The Brazilian phenotypic distribution shows great heterogeneity throughout the latitudes. In the states of Santa Catarina and Rio Grande do Sul, $89 \%$ of the population in the urban areas have fair skin. ${ }^{40}$ Although our work did not assess the skin color of 
TABLE 4: CM Distribution according to location, Clark's level, Breslow's depth, and histological type

\begin{tabular}{|c|c|c|c|c|c|c|}
\hline \multirow[t]{2}{*}{$\mathrm{CM}$ characteristics } & \multicolumn{5}{|c|}{ Location } & \multirow[t]{2}{*}{ P-value } \\
\hline & $\begin{array}{c}\text { Head/neck } \\
\text { n (\%) }\end{array}$ & $\begin{array}{c}\text { Lower limb } \\
\text { n (\%) }\end{array}$ & $\begin{array}{c}\text { Upper limb } \\
\text { n (\%) }\end{array}$ & $\begin{array}{c}\text { Skin, WFS } \\
\mathrm{n}(\%)\end{array}$ & $\begin{array}{l}\text { Trunk } \\
\mathrm{n}(\%)\end{array}$ & \\
\hline Clark's level & & & & & & $<0.001$ \\
\hline I & $52(31.1)^{*}$ & $26(16.1)$ & $48(22.2)$ & $4(30.8)$ & $73(23.8)$ & \\
\hline II & $35(21.0)$ & $26(16.1)$ & $50(23.1)$ & $1(7.7)$ & $61(19.9)$ & \\
\hline III & $30(18.0)$ & $44(27.3)$ & $66(30.6)$ & $3(23.1)$ & $89(29.0)$ & \\
\hline IV & $36(21.6)$ & $50(31.1)^{*}$ & $50(23.1)$ & $4(30.8)$ & $76(24.8)$ & \\
\hline $\mathrm{V}$ & $14(8.4)^{*}$ & 15 & $2(0.9)$ & $1(7.7)$ & $8(2.6)$ & \\
\hline Breslow's depth & & & & & & 0.004 \\
\hline In situ & 52 & $26(16.5)$ & $48(21.9)$ & $4(30.8)$ & $73(23.9)$ & \\
\hline S I & $55(33.7)$ & $65(41.1)$ & $110(50.2)^{*}$ & $3(23.1)$ & $136(44.4)$ & \\
\hline S II & 19 (11.7) & $25(15.8)$ & $24(11.0)$ & $1(7.7)$ & $43(14.1)$ & \\
\hline S III & $14(8.6)$ & $24(15.2)^{*}$ & $22(10.0)$ & $2(15.4)$ & $19(6.2)$ & \\
\hline S IV & $23(14.1)$ & 18 (11.8) & $15(6.8)$ & $3(23.1)$ & 35 (11.4) & \\
\hline Histological type & & & & & & $<0.001$ \\
\hline LMM & $41(23.3)^{*}$ & $12(7.2)$ & $18(8.0)$ & $0(0)$ & $20(6.4)$ & \\
\hline ALM & 0 & $8(4.8)^{*}$ & $2(0.9)$ & $0(0)$ & $0(0)$ & \\
\hline NM & $40(22.7)$ & $37(22.3)$ & $38(17.0)$ & $5(35.7)$ & $48(15.3)$ & \\
\hline SSM & 68 (38.6) & $87(52.4)$ & $151(67.4)^{*}$ & $7(50.0)$ & $203(64.9)^{*}$ & \\
\hline WFS & $21(11.9)$ & 17 (10.2) & $14(6.3)$ & $2(14.3)$ & 35 (11.2) & \\
\hline Others & $6(3.4)$ & $5(3.0)$ & $1(0.5)$ & $0(0)$ & $7(2.2)$ & \\
\hline
\end{tabular}

Notes: $\mathrm{LMM}=$ lentigo maligna melanoma; ALM = acral lentiginous melanoma; NM = nodular melanoma; $\mathrm{SSM}=$ superficial spreading melanoma; and WFS = without further specifications

the individuals, we believe that the observed high rates are partly associated with a higher proportion of light-skinned residents, as most new cases of CM are known to occur in whites compared to other ethnic groups. An example of this are the findings of a study conducted in the USA between 2008 and 2012, where the number of new cases was 33.0 and 20.2 per 100,000 white men and women, respectively, while among blacks, the indices were lower (1.2 and 1.0 cases per 100,000 black men and women, respectively). ${ }^{16}$ In Blumenau, CIWP was calculated in 27.8 cases in 1985; 25.5 in 2001; and 23.1 in 2007 per 100,000 population, values close to those expected for descendants of Germans and Italians who colonized that geographic region with high UVR levels. ${ }^{41}$ A population-based study that evaluated the cases recorded between 1988 and 2000 in the city of Goiânia, composed of a mixed population, reported that the average CIWP (world standard population of Segi, 1960) was 2.78 in women and 3.49 in men per 100,000 population. ${ }^{30}$

When stratified by gender, the difference between CIWP in the periods 2003-06 and 2011-14 was statistically significant, with a higher increase among women (51\%) than among men (44\%). This observation is different from the trend for a more pronounced increase in men reported in the southern region of Brazil, as well as in other countries. ${ }^{2}$

Regarding age, $\mathrm{CM}$ is characterized by affecting younger in- dividuals, with a mean age at diagnosis of 52 years, 10 years younger than patients affected by more common cancers such as breast, lung, and prostate (except noncutaneous melanoma). ${ }^{37}$ The present study confirmed this characteristic of $\mathrm{CM}$ when it revealed an average age of 54.6 years. In the US, between 2008 and 2012, the mean age at diagnosis for $\mathrm{CM}$ was 63 years, with the majority of patients being diagnosed between 55 and 64 years. ${ }^{34}$ Another finding in this study was that the mean age at diagnosis was higher among men ( 55.9 years) than among women (53.9 years). This was similar to a German study conducted between 1998 and 2001, in which the mean age for men was also higher than that for women (56.6 versus 54.9 years, $\mathrm{p}<0.05){ }^{42}$ In the elderly age group, we observed more CMs located on the head and neck, whereas in the group composed of young patients, CMs predominately affected the trunk and the upper limb. Similarly, in the United States, between 1999 and 2006, head and neck CMs occurred in individuals older than those with CMs affecting other skin locations. Meanwhile, patients with $\mathrm{CM}$ affecting the trunk were younger at the time of diagnosis. ${ }^{43}$ The predominance of head and neck location was also observed in the elderly in Latvia and France. ${ }^{4,38}$

We observed a predominance of NM and LMM cancer types in the elderly, with thicker CMs. Also, this group presented with the highest number of primary CMs. Similarly, in a rural region in northern France (Champagne-Ardenne), the elderly group was 
characterized by a more advanced stage at the time of diagnosis, with a higher proportion of ulcerated tumors and with much larger Breslow measurements. ${ }^{38}$

In the studied period, most CM cases in Joinville (56\%) occurred in women. These findings are in agreement with the literature, because in regions where the incidence of $\mathrm{CM}$ is intermediate, such as Europe and Brazil, there is a predominance of females. On the other hand, in places with a much higher incidence, such as Australia, New Zealand and the USA, there is a predominance of males or gender equality. ${ }^{37,42}$

CMs develop more often on the face. Historically, body sites most commonly affected include ears, head, neck, back, and shoulders in men, and lower limbs in women. ${ }^{1,10}$ In our study, the most frequent location was the trunk (35.1\%), followed by the upper limb (25.1\%), and head and neck (19.7\%). The least frequent location was the lower limb (18.6\%). Between 1980 and 1995, in Aruba, the most frequent locations of CM were the legs (33.3\%), the back $(25.9 \%)$, and the face $(18.5 \%) .{ }^{44}$ In a French study, in a predominantly rural population, the most frequent anatomical location was the head and neck $(59.3 \%)$, followed by the lower limbs (17\%), trunk (12.4\%), and upper limbs (11.3\%). ${ }^{38}$

Among women, we observed a predominance of CM affecting the lower limb and, in the men, the head/neck or the trunk were more commonly affected $(p<0.0001)$. This gender difference

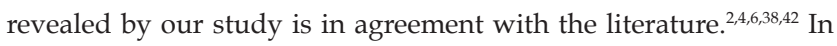
Londrina (state of Paraná) and in the state of Rio Grande do Sul, studies have identified the same tumor locations. ${ }^{2,45}$ Criado et al. (1999) observed a 2.3-fold higher risk for men to develop CM in the posterior trunk region, while the probability of lower limb involvement was 2.4 times higher in females. ${ }^{2}$ This classical difference between the sexes has been reported for more than 30 years in various populations, and persists in some recent studies. ${ }^{38}$

Thick primary $\mathrm{CM}$ is associated with several factors, including older age, male sex, being single (separated, divorced, or widowed), low level of schooling, obesity, autodetection or detection by general practitioner, and CM of the head-neck and lower limbs. ${ }^{9}$

SSM was the most prevalent type in our study (58\%), in agreement with the findings of a German study, in which the lesion represented $39.1 \%$ of the cases. ${ }^{42}$ Regarding location, our study revealed a predominance of LMM affecting the head and neck, ALM affecting the lower limb, and SSM affecting the upper limb and trunk. Similarly, the study conducted in Londrina also identified a predominance of LMM on the head and neck and SSM on the trunk..$^{45}$

It is noteworthy that NM and ALM together represent 20\% of $\mathrm{CM}$ cases diagnosed during the study period in Joinville. These histological types comprise the group of thick CMs due to a more aggressive behavior or late recognition, since they are often amelanotic or have atypical clinical appearance. These forms of $\mathrm{CM}$ are particularly prone not to be recognized by classical criteria, such as the $A B C D$ rule. Campaigns aimed at improving early diagnosis and reducing mortality should target particularly those more serious types of $\mathrm{CM}^{38}$

When comparing CMs diagnosed in the $21^{\text {st }}$ century with CMs diagnosed between 1972 and 1982, it is possible to notice improvements in the early detection of SSM, but not of NM. SSM is typically diagnosed when it is still thin and has lower rates of ulceration as opposed to NM. Previous data have established that NM is often detected with $2 \mathrm{~mm}$ or more. A study on cancer registry in Queensland, Australia (2009), identified the profile of individuals at the highest risk of developing thick NMs: men, older individuals, and those who have not been examined by a physician in the last three years. ${ }^{10}$

$\mathrm{CM}$ survivors are at a higher risk of developing other subsequent primary cancers. ${ }^{11}$ The history of previous $\mathrm{CM}$ is among the strongest predictors for the development of a subsequent $\mathrm{CM}$ and, to a lesser extent, for basal cell carcinoma (BCC) or squamous cell carcinoma (SCC). Therefore, secondary prevention is critical for patients with a history of CM. These patients should be well informed about the risk of subsequent skin cancer development and the need for sun protection. ${ }^{14}$ In the study period, $6.5 \%$ of the subjects had more than one primary $\mathrm{CM}$. The frequency we found for individuals with multiple CMs is in accordance with the literature, which reports incidence rates between 0.5 and $8.6 \%{ }^{4,46}$

We observed that the mean time between CMs was approximately 2 years. In a study conducted in Latvia, the following primary $\mathrm{CM}$ appeared during the first year after the initial diagnosis in $29-59 \%$ of cases. ${ }^{4}$

The majority of recidivist subjects $(74 \%)$ were affected by up to 2 primary CMs. In individuals with multiple CMs, it is interesting to note that there were fewer NM and more SSM tumors $(p=0.021)$, and the new CM occurred more on the upper limb ( $p=$ 0.033 ). A positive history of $\mathrm{CM}$ is related to a 10 -fold increased risk for developing a subsequent $\mathrm{CM}$. These subsequent tumors tend to be thinner than the primary CMs, probably because of the intensification of physical examinations during clinical follow-up. ${ }^{14}$

Savoia et al. (2012), in a single-institution database with 4,938 patients diagnosed with CM, observed the characteristics of 270 patients who had 639 multiple primary CMs over 34 years. Most of them $(76.7 \%)$ developed only one new lesion. The authors also observed a significantly lower mean Breslow thickness in the new lesion ( $p$ <.001) and a smaller number of NM. Interestingly, the prognosis of those who had multiple CMs was better than in those with a single lesion. ${ }^{46}$

The increased risk of developing CM, BCC, or SCC after the first CM suggests a partially common etiology of RUV-induced field canceration and genetic predisposition among these three types of skin cancer. The risk is twice as high to develop a BCC than an SCC after a CM. An explanation for this phenomenon could be the fact that BCC and CM share intermittent exposure to UVR and sunburn as a common risk factor, whereas SCC development is associated with cumulative exposure to UVR. More likely, the increased risk of developing a SCC after a CM may be driven by the LMM subtype, which affects more often the face and is also associated with chronic and elevated levels of UVR exposure. ${ }^{14}$

Patients with CM need to be informed about their future persistent risk, should be motivated to perform self-examination and, if possible, should have their entire body skin examined by trained physicians in order to early detect a secondary CM. ${ }^{14}$

As a limitation to this study, we can mention the adopted design, which used secondary data. However, considering the magnitude of our sample, we believe that some possible bias may have 
been minimized without causing greater interference in the results presented here.

\section{CONCLUSION}

Joinville revealed high incidence coefficients for Brazilian standards, with an observed increase in CM incidence in the study period.
We believe that our findings can help improve early detection campaigns, since knowledge of the local reality is an essential tool to cope with this disease. Planned primary and secondary prevention actions are considered the cornerstone to reduce the burden of $\mathrm{CM}^{47}$ Considering that the incidence of $\mathrm{CM}$ continues to increase, the significant burden related to its morbidity and mortality, and the considerable economic costs, timely recognition, assessment, and management of $\mathrm{CM}$ should be a priority in public health actions. ${ }^{48}$

\section{REFERENCES}

1. Vries E, Bray F, Coebergh JW, et al. Melanocytic tumours. In: LeBoit PE, Burg G, Weedon D, Sarasin A, editores. World Health Organization classification of tumours: pathology and genetics, skin tumour. 3. ed. Lyon: International Agency for Research on Cancer; 2006. p 49-120.

2. Anger M, Friedhofer H, Fukutaki MF, Ferreira MC, Landman G. Primary cutaneous melanoma: an 18year study. Clinics (Sao Paulo). 2010;65:257-63.

3. Cavarsan F. Epidemiologia do melanoma no Brasil. In: Wainstein A, Belfort F. Melanoma: prevenção, diagnóstico, tratamento e acompanhamento. 2. ed. São Paulo: Atheneu; 2014. p.11-22.

4. Azarjana K, Ozola A, Ruklisa D, Cema I, Rivosh A, Azaryan A, et al. Melanoma epidemiology, prognosis and trends in Latvia. J Eur Acad Dermatol Venereol. 2013;27:1352-9.

5. Garbe C, J Bauer. Melanoma. In: Bolognia JL, Jorizzo JL, Schaffer JV, editores. Dermatologia. 3. ed. Rio de Janeiro: Elsevier, 2015. p. 1885-914.

6. Kocarnik JM, Park SL, Han J, Dumitrescu L, Cheng I, Wilkens LR, et al. Replication of associations between GWAS SNPs and melanoma risk in the Population Architecture using Genomics and Epidemiology (PAGE) study. J Invest Dermatol. 2014;134:2049-2052.

7. Mar V, Wolfe R, Kelly JW. Predicting melanoma risk for the Australian population. Australas J Dermatol. 2011;52:109-16.

8. Silverberg Jl, Ratner D. Associations of nonmelanoma skin cancer and melanoma extracutaneous cancers and smoking in adults: a US populationbased study. J Eur Acad Dermatol Venereol. 2015;29:1389-97.

9. Skowron F, Bérard F, Balme B, Maucort-Boulch D. Role of obesity on the thickness of primary cutaneous melanoma. J Eur Acad Dermatol Venereol. 2015;29:262-9.

10. Mayer JE, Swetter SM, Fu T, Geller AC. Screening, early detection, education, and trends for melanoma: current status (20072013) and future directions: Part I. Epidemiology, high-risk groups, clinical strategies, and diagnostic technology. J Am Acad Dermatol. 2014;71:599.e1-599.e12.

11. Balamurugan A, Rees JR, Kosary C, Rim SH, Li J, Stewart SL. Subsequent primary cancers among men and women with in situ and invasive melanoma of the skin. J Am Acad Dermatol. 2011;65:S69-77.

12. Segatto MM, Bonamigo RR, Hohmann CB, Müller KR, Bakos L, Mastroeni S, et al. Residential and occupational exposure to pesticides may increase risk for cutaneous melanoma: a casecontrol study conducted in the south of Brazil. Int $\mathrm{J}$ Dermatol. 2015;54:e527-38.

13. Dennis LK, Lynch CF, Sandler DP, Alavanja MC. Pesticide use and cutaneous melanoma in pesticide applicators in the agricultural heath study. Environ Health Perspect. 2010;118:812-7

14. van der Leest RJ, Flohil SC, Arends LR, de Vries E, Nijsten T. Risk of subsequent cutaneous malignancy in patients with prior melanoma: a systematic review and metaanalysis. J Eur Acad Dermatol Venereol. 2015;29:1053-62.

15. Canceraustralia.gov.au [Internet]. Melanoma of the skin statistics. Surry Hills: Australian Government, Cancer Australia [cited 2015 Nov 15]. Available

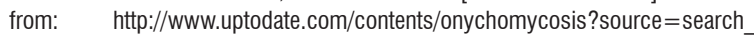
result\&search $=$ onicomicose\&selectedTitle $=1 \% 7 \mathrm{E} 23$ statistics.

16. Seer.cancer.gov [Internet]. National Cancer Institute. SEER stat fact sheets: Melanoma of the skin. Bethesda: National Cancer Institute Surveillance, Epidemiology, and End Results Program. [cited 2015 nov 15]. Available from: http://seer.cancer.gov/statfacts/html/melan.html.
17. Patrawala S, Maley A, Greskovich C, Stuart L, Parker D, Swerlick R, et al. Discordance of histopathologic parameters in cutaneous melanoma: clinical implications. J Am Acad Dermatol. 2016;74:75-80.

18. Ekwueme DU, Guy GP Jr, Li C, Rim SH, Parelkar P, Chen SC. The health burden and economic costs of cutaneous melanoma mortality by race/ethnicityUnited States, 2000 to 2006. J Am Acad Dermatol. 2011:65:S133-43.

19. Eco.iarc.fr [Internet]. Malignant melanoma of skin. Lyon: International Agency for Research on Cancer EUCAN. [cited 2015 nov 15]. Available from: http://eco.iarc. fr/eucan/Cancer.aspx?Cancer=20\#blockmapa.

20. Inca.gov.br [Internet]. Estimativas para 0 ano de 2014 das taxas brutas de incidência por 100 mil habitantes e do número de casos novos de câncer, segundo sexo e localização primária. Rio de Janeiro: Instituto Nacional do Câncer [acesso 9 nov 2015]. Disponivel em: http://www.inca.gov.br/estimativa/2014/ tabelaestados.asp?UF=BR.

21. Inca.gov.br [Internet]. Estimativa 2014: incidência de câncer no Brasil. Síntese de resultados e comentários. Rio de Janeiro: Instituto Nacional de Câncer. [acesso 9 nov 2015]. Disponível em: http://www.inca.gov.br/estimativa/2014/ sintesederesultadoscomentarios.asp.

22. Instituto Nacional de Câncer José Alencar Gomes da Silva. Coordenação de Prevenção e Vigilância. Estimativa 2014: incidência de Cancer no Brasil [Internet]. Rio de Janeiro: Inca;2014. [acesso 9 nov 2015]. Disponível em: http://www. saude.sp.gov.br/resources/ses/perfil/gestor/homepage/outros-destaques/ estimativa-de-incidencia-de-cancer-2014/estimativa_cancer_24042014.pdf

23. Bonilla NMF. Registro da incidência de câncer na cidade de Joinville e uso da técnica de geoprocessamento [dissertação]. Univille: Universidade da Região de Joinville; 2007.

24. Cidades.ibge.gov.br. [Internet]. Instituto Brasileiro de Geografia e Estatística. IBGE | Cidades | Santa Catarina |joinville| Histórico. 2016 [acesso 9 nov 2015]. Disponível em: http://www.cidades.ibge. gov.br/painel/historic 0 . php ?lang $=\&$ codmun $=420910 \&$ search $=$ santa catarina|joinville|infograficos:historico.

25. Chiba FB, Schettini APM, Delfino ACG, Chirano CA, Damasceno SAS. Perfil clínico epidemiológico dos melanomas cutâneos em duas instituições de referência na cidade de Manaus, Brasil. An Bras Dermatol. 2011;86:1239-41.

26. Secretaria Municipal da Saúde de Joinville. População residente por unidade de saúde, por bairro, faixa etária e sexo. Joinville: Secretaria Municipal da Saúde; 2014.

27. Tabnet.datasus.gov.br [Internet]. DATASUS População residente no Brasil DataSUS. Brasília: Ministério da Saúde; 2010. [acesso 10 set 2015]. Disponível em: http://tabnet.datasus.gov.br/cgi/deftohtm.exe?ibge/cnv/popuf.def.

28. Secretaria Municipal de Saúde de Joinville. População residente por unidade de saúde, por bairro, faixa etária e sexo. Joinville: Secretaria Municipal da Saúde; 2013.

29. Jekel JS, Elmore JG, Katz DL. Epidemiologia, Bioestatística e Medicina Preventiva. 2. ed. Porto Alegre: ArtMed; 2005.

30. Sortino-Rachou AM, Curado MP, Latorre MRDO. Melanoma cutâneo: estudo de base populacional em Goiânia, Brasil, 1988 2000. An Bras Dermatol. 2006;81:449-55.

31. Who.int [Internet]. Ahmad OB, Pinto CB, Lopez AD, Murray CJL, Lozano R, Inoue M. Age standardization of rates: a new WHO standard. Geneva: World Health Organization. [acesso 15 nov 2015]. Disponivel em: http://www.who.int/ healthinfo/paper31.pdf. 
32. Census.gov [Internet]. World population by age and sex. Washington: United States Census Bureau. [cited 2015 Nov 9]. Disponivel em: http://www.census. gov/population/international/data/worldpop/tool_population.php.

33. Tabnet.datasus.gov.br [Internet]. População residente no Brasil por sexo segundo faixa etária detalhada DataSUS. Brasilia: Ministério da Saúde. [acesso em 2015]. Disponivel em: http://tabnet.datasus.gov.br/cgi/tabcgi.exe ibge/cnv/popuf.def.

34. Seer.cancer.gov [Internet]. World (20002025) Standard. Bethesda: National Cancer Institute Surveillance, Epidemiology, and End Results Program. [cited 2015 Nov 15]. Available from: http://seer.cancer.gov/stdpopulations/world. who.html.

35. Brasil. Decreto no 2.026, de 16 de dezembro de 2008. Regulamenta a Lei no 12.989, de 01 de junho de 2004, que autoriza o Poder Executivo a instituir 0 Sistema Estadual de Registro de Câncer no Estado de Santa Catarina. Diário Oficial da União 16 dez 2008. [acesso 23 jan 2016]. Disponível em: http://www. dive.sc.gov.br/conteudos/publicacoes/Legislacao/Decreto_N_2026_2008_ Registro_do Cancer.pdf

36. Vigilantos.dive.sc.gov.br [Internet]. Florianópolis: Diretoria de vigilância epidemiológica. [acesso $15 \mathrm{dez}$ 2015] Disponível em: http://www.previdencia. gov.br/servicos-ao-cidadao/todos-os-servicos/comunicacao-de-acidente-detrabalho

37. Brandão FV, Pereira AF, Gontijo B, Bittencourt FV. Aspectos epidemiológicos do melanoma em serviço de dermatologia de hospital universitário em um período de 20 anos. An Bras Dermatol. 2013;88:344-53.

38. Barbe C, Hibon E, Vitry F, Le Clainche A, Grange F. Clinical and pathological characteristics of melanoma: a population-based study in a French regional population. J Eur Acad Dermatol Venereol. 2012;26:159-64.

39. Basepop.incidencia.inca.gov.br [Internet]. Registros de Câncer de Base Populacional Florianópolis. Taxas de incidência segundo localização do câncer primário. Rio de Janeiro: Instituto Nacional do Câncer. [acesso 15 nov 2015]. Disponivel em: http:// basepop.incidencia.inca.gov.br/BasePoplncidencias/Home.action.

40. Fabris MR, Durães ES, Martignago BC, Blanco LF, Fabris TR. Avaliação do conhecimento quanto à prevenção do câncer de pele e sua relação com os hábitos da exposição solar e fotoproteção em praticantes de academia de ginástica do sul de Santa Catarina, Brasil. An Bras Dermatol. 2012;87:36-43.

41. Nasser N. Melanoma cutâneo estudo epidemiológico de 30 anos em cidade do Sul do Brasil, de 19802009. An Bras Dermatol. 2011:86:932-41.

42. Katalinic A, Kunze U, Schäfer T. Epidemiology of cutaneous melanoma and nonmelanoma skin cancer in SchleswigHolstein, Germany: incidence, clinical subtypes, tumour stages and localization (epidemiology of skin cancer). $\mathrm{Br} \mathrm{J}$ Dermatol. 2003;149:1200-6.
43. Wu XC, Eide MJ, King J, Saraiya M, Huang Y, Wiggins C, et al. Racial and ethnic variations in incidence and survival of cutaneous melanoma in the United States, 19992006. J Am Acad Dermatol. 2011;65:S26-37.

44. Kennedy C, Bajdik CD. Descriptive epidemiology of skin cancer on Aruba: 19801995. Int J Dermatol. 2001:40:169-74.

45. Gon AS, Minelli L, Guembarovski AL. Melanoma cutâneo primário em Londrina. An Bras Dermatol. 2001;76:413-26.

46. Savoia P, Osella-Abate S, Deboli T, Marenco F, Stroppiana E, Novelli M, et al. Clinical and prognostic reports from 270 patients with multiple primary melanomas: a 34 year singleinstitution study. J Eur Acad Dermatol Venereol. 2012;26:882-8.

47. Stratigos AJ, Forsea AM, van der Leest RJ, de Vries E, Nagore E, Bulliard JL, et al. Euromelanoma: a dermatologyled European campaign against nonmelanoma skin cancer and cutaneous melanoma. Past, present and future. Br J Dermatol. 2012;167:99-104

48. Krige JE, Isaacs S, Hudson DA, King HS, Strover RM, Johnson CA. Delay in the diagnosis of cutaneous malignant melanoma: a prospective study in 250 patients. Cancer. 1991;68:2064-8.

How to cite this article: Steglich RB, Coelho KMPA, Cardoso S, Gaertner MHCN, Cestari TF, Franco SC. Epidemiological and histopathological aspects of primary cutaneous melanoma in residents of Joinville, 2003-2014. An Bras Dermatol. 2018;93(1):45-53. 